Prepared in cooperation with The Nature Conservancy

\title{
Economic Effects of Wildfire Risk Reduction and Source Water Protection Projects in the Rio Grande River Basin in Northern New Mexico and Southern Colorado
}

Open-File Report 2019-1108

U.S. Department of the Interior U.S. Geological Survey 
Front Cover. A prescribed burn in New Mexico in April 2016 (Credit: Collin Haffey, The Nature Conservancy). Used with permission.

Back Cover. (top right) A forestry crew in New Mexico thinning a stand of Pinus ponderosa (ponderosa pine) in October 2018 (Credit: Mark Schuetz, volunteer with The Nature Conservancy). (bottom) Forest thinning crews preparing for a prescribed burn in New Mexico in March 2019 (Credit: Collin Haffey, The Nature Conservancy). (left) A stand of Pinus ponderosa (ponderosa pine) located in New Mexico in July 2018 (Credit: Jackie Hall, The Nature Conservancy). Used with permission. 


\section{Economic Effects of Wildfire Risk Reduction and Source Water Protection Projects in the Rio Grande River Basin in Northern New Mexico and Southern Colorado}

By Christopher Huber, Catherine Cullinane Thomas, James R. Meldrum, Rachel Meier, and Steven Bassett

Prepared in cooperation with The Nature Conservancy

Open-File Report 2019-1108 


\title{
U.S. Department of the Interior DAVID BERNHARDT, Secretary
}

\author{
U.S. Geological Survey \\ James F. Reilly II, Director
}

U.S. Geological Survey, Reston, Virginia: 2019

For more information on the USGS - the Federal source for science about the Earth, its natural and living resources, natural hazards, and the environment-visit https://www.usgs.gov or call 1-888-ASK-USGS.

For an overview of USGS information products, including maps, imagery, and publications,

visit https://store.usgs.gov.

Any use of trade, firm, or product names is for descriptive purposes only and does not imply endorsement by the U.S. Government.

Although this information product, for the most part, is in the public domain, it also may contain copyrighted materials as noted in the text. Permission to reproduce copyrighted items must be secured from the copyright owner.

Suggested citation:

Huber, C., Cullinane Thomas, C., Meldrum, J.R., Meier, R., and Bassett, S., 2019, Economic effects of wildfire risk reduction and source water protection projects in the Rio Grande River Basin in northern New Mexico and southern Colorado: U.S. Geological Survey Open-File Report 2019-1108, 8 p., https://doi.org/10.3133/ofr20191108.

ISSN 2331-1258 (online) 


\section{Acknowledgments}

This project was supported by the Social and Economic Analysis Branch of the U.S. Geological Survey Fort Collins Science Center, the U.S. Geological Survey Sustaining Environmental Capital Initiative, and The Nature Conservancy.

\section{Contents}

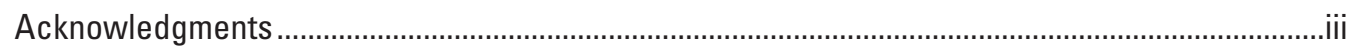

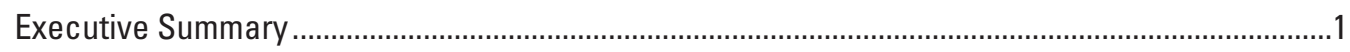

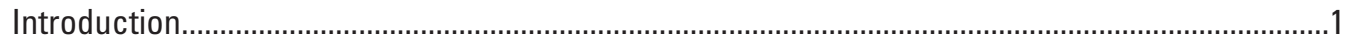

Economic Impact Analysis Methods and Data Requirements.....................................................

Rio Grande Water Fund Project Expenditure Data Collection....................................................

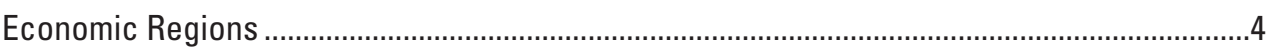

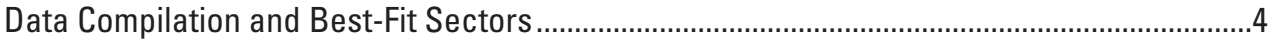

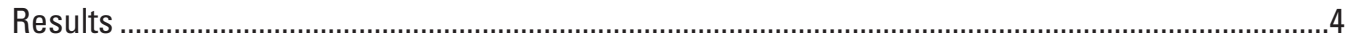

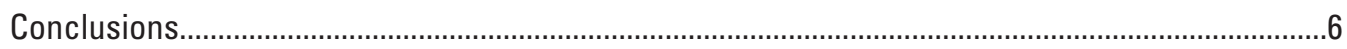

References Cited.

\section{Figure}

1. Thirteen-county local economic region included in Rio Grande River Basin wildfire risk reduction and source water protection projects area in northern New Mexico and southern Colorado. Bernalillo, Los Alamos, Mora, Valencia, Rio Arriba, Santa Fe, Sandoval, San Miguel, Taos, and Torrance Counties are in New Mexico, and Archuleta, Conejos, and Costilla Counties are in Colorado. 3

\section{Tables}

1. Restoration activity, best-fit IMPLAN sector, and sector description of expenditures made by the Rio Grande Water Fund (RGWF), 2018.

2. Rio Grande Water Fund expenditure categories by IMPLAN sector, total project expenditures in the Western States region, local project expenditures in the 13-county Rio Grande Water Fund project area in northern New Mexico and southern Colorado, 2018, as a result of investments made by the Rio Grande Water Fund (RGWF)

3. Economic impacts of project expenditures in the 13-county local region of the Rio Grande Water Fund (RGWF) project area, in northern New Mexico and southern Colorado

4. Economic impacts of project expenditures in the Western States region, beyond the immediate 13-county Rio Grande Water Fund project area in northern New Mexico and southern Colorado 


\section{Conversion Factors}

U.S. customary units to International System of Units

\begin{tabular}{|c|c|c|}
\hline Multiply & By & To obtain \\
\hline \multicolumn{3}{|c|}{ Area } \\
\hline acre & 0.004047 & square kilometer $\left(\mathrm{km}^{2}\right)$ \\
\hline
\end{tabular}

\section{Abbreviations}

$\begin{array}{ll}\text { BLM } & \text { U.S. Bureau of Land Management } \\ \text { DOI } & \text { U.S. Department of the Interior } \\ \text { GDP } & \text { Gross domestic product } \\ \text { GRP } & \text { Gross regional product } \\ \text { NAICS } & \text { North American Industry Classification System } \\ \text { NRDA Restoration Program } & \begin{array}{l}\text { DOI Natural Resource Damage Assessment and Restoration } \\ \text { Program }\end{array} \\ \text { RGWF } & \text { Rio Grande Water Fund } \\ \text { TNC } & \text { The Nature Conservancy } \\ \text { U.S. } & \text { United States } \\ \text { USFS } & \text { U.S. Forest Service } \\ \text { USGS } & \text { U.S. Geological Survey }\end{array}$




\title{
Economic Effects of Wildfire Risk Reduction and Source Water Protection Projects in the Rio Grande River Basin in Northern New Mexico and Southern Colorado
}

\author{
By Christopher Huber, ${ }^{1}$ Catherine Cullinane Thomas, ${ }^{1}$ James R. Meldrum, ${ }^{1}$ Rachel Meier, ${ }^{2}$ and Steven Bassett ${ }^{2}$
}

\section{Executive Summary}

This report investigates how investments made by the Rio Grande Water Fund (RGWF) in wildfire risk reduction and source water protection projects in northern New Mexico and southern Colorado affect local economic activity. These investments also support jobs and generate business sales activities within nearby local economies. The RGWF project area evaluated in this report consists of 13 counties in northern New Mexico and southern Colorado that are within a 17-State region referred to here as the Western States. To implement these projects, the RGWF spent a total of $\$ 855,000$ in 2018 on contractors located in the Western States regional economy. In the Western States, including direct and secondary effects, these expenditures supported an estimated 22 jobs, $\$ 1,089,000$ in labor income, $\$ 1,324,000$ in value added, and $\$ 1,907,000$ in economic output. The majority (73 percent or $\$ 623,000$ ) of these expenditures were made by hiring local businesses operating within the 13 -county region in northern New Mexico and southern Colorado RGWF project area. Within the RGWF project area, including direct and secondary effects, local expenditures supported an estimated 15 jobs, $\$ 676,000$ in labor income, $\$ 791,000$ in value added, and $\$ 1,120,000$ in economic output. These results established that investments in wildfire risk reduction and source water protection projects can support jobs, generate business sales activities within nearby local economies and enhance livelihoods, small businesses, and rural economies in the Mountain West.

\section{Introduction}

Understanding the restoration economy is a growing body of research. Past studies include the economic impacts of the U.S. Fish and Wildlife Service's Partners for Fish and Wildlife and Coastal Programs (Laughland and others, 2014), the U.S. Forest Service (USFS) fuels reduction projects and the Collaborative Forest Landscape Restoration Program (Hjerpe and Kim, 2008; Kim, 2010; Southwick Associates and Responsive Management, 2013; U.S. Department of Agriculture, 2015), and the coastal restoration projects by the National Oceanic and Atmospheric Administration (Edwards and others, 2013). There are also several studies that estimate the economic effects of restoration projects within individual states, regions, or to the Nation (Wagner and Shropshire, 2009; Nielsen-Pincus and Moseley, 2010; Industrial Economics, 2012; Headwaters Economics, 2014; BenDor and others, 2015). The U.S. Geological Survey (USGS) recently published a report summarizing a series of case studies on the economic impacts of projects associated with the U.S. Department of the Interior (DOI) Natural Resource Damage Assessment and Restoration (NRDA Restoration Program) and the Bureau of Land Management (BLM) (Cullinane Thomas and others, 2016). In coordination with DOI and BLM, USGS designed and administered a survey to collect restoration expenditure data at a projectlevel scale and used these data to estimate the economic effects of case study restoration projects. This current analysis builds from this existing USGS research and utilizes a modified survey described in Cullinane Thomas and others (2016).

For this analysis, the economic impacts of wildfire risk reduction and source water protection projects coordinated by The Nature Conservancy (TNC) through the Rio Grande Water Fund (RGWF) are estimated. Launched in 2014, the RGWF represents a collaborative partnership including a wide variety of State, Federal, local, private, non-profit, and tribal organizations and agencies, with 80 signatories as of June 2019 (see http://riograndewaterfund.org). The RGWF seeks to protect both natural and artificial water storage (for example, wetlands and reservoirs), delivery, and quality of Rio Grande water through landscape-scale

\footnotetext{
${ }^{1}$ U.S. Geological Survey
}

${ }^{2}$ The Nature Conservancy 
restoration treatments in tributary forested watersheds across a 7-million-acre area, covering portions of 13 counties in northern New Mexico and southern Colorado (fig. 1). Supported by a broad public-private partnership, the RGWF provides funding for projects that are intended to accelerate landscape-scale forest restoration, primarily in Pinus ponderosa (ponderosa pine) and dry mixed conifer forests, and aims to sustain treatments over 20 years, with 30,000 acres restored per year in the Rio Grande, Rio Chama, and tributary watersheds. Restoration treatments include thinning, controlled burns, stream restoration, post-fire watershed restoration, restoration planning, education and outreach, and monitoring (TNC, 2014). This report focuses on the immediate economic impacts generated through expenditures on restoration activities made by the RGWF in 2018. It is important to recognize that the economic impact estimates in this report are only part of the full economic, social, and ecological effects of RGWF projects. For example, these economic impact measures are distinctly different from the economic benefits (or values) that individual people receive from improved outdoor recreation access (Loomis and Walsh, 1997), improved water quality (Johnston and others, 2016), and preservation of wildlife (Richardson and Loomis, 2009). These and other outcomes often require nonmarket valuation methods to quantify their economic benefits to society (see Champ, Boyle, and Brown [2017] for additional information on nonmarket valuation methods).

\section{Economic Impact Analysis Methods and Data Requirements}

Economic impact analyses measure the jobs and business activity generated through new expenditures in an economy (Loomis, 2002; Cullinane Thomas and others, 2016). These include the direct jobs and economic activity supported by expenditures on restoration activities, as well as the secondary effects of those expenditures. Economic input-output models describe the interaction between producers and consumers within an economy and are used to measure the direct and secondary effects of project expenditures using regional economic multipliers.

Economic impacts of RGWF projects in 2018 are estimated by applying project-level expenditures to IMPLAN inputoutput modeling software and data system (IMPLAN Group LLC., 2018). The IMPLAN Pro v3.1 2017 National Data Set is used for this study. The Western States IMPLAN model includes Arizona, California, Colorado, Idaho, Kansas, Montana, Nebraska, Nevada, New Mexico, North Dakota, Oklahoma, Oregon, South Dakota, Texas, Utah, Washington, and Wyoming. This matches the 17-State regional economy Cullinane Thomas and others (2016) used to define and analyze the effects of previous BLM restoration projects. A multi-county IMPLAN model is used to estimate the local impacts for the 13-county RGWF project area in northern New Mexico and southern Colorado. A 17-State model is used to represent the Western States regional economy. All impacts are estimated in 2018 dollars. The types of economic impacts measured in this analysis include:

- Jobs: The combined total number of annualized full and part-time jobs supported by RGWF projects in 2018.

- Labor income: The wages and salaries earned through RGWF project expenditures. Labor income includes employee wages and payroll benefits, as well as the incomes of sole proprietors.

- Value added: Value added is an equivalent measure to gross regional product (GRP) and measures the value of the goods and services produced by a regional economy each year (for example, thirteen-county RGWF project area and Western States economies, respectively); GRP is an analogous measure to gross domestic product (GDP) for the U.S. economy; value added is thus the most appropriate measure to explain how restoration projects contribute to GRP. Value added is equal to the value of the production of goods and services (gross output) minus the cost of intermediate inputs (goods and services purchased from other industries).

- Economic output: A measure of the total value of the production of goods and services supported by RGWF project expenditures. Output is equal to the sum of all intermediate sales (business to business sales) and final demand (sales to consumers).

To estimate the economic impacts of RGWF projects in 2018, it is necessary to gather project-level cost data, define the economic regions, and bridge expenditures to best-fit sectors of the economy. 


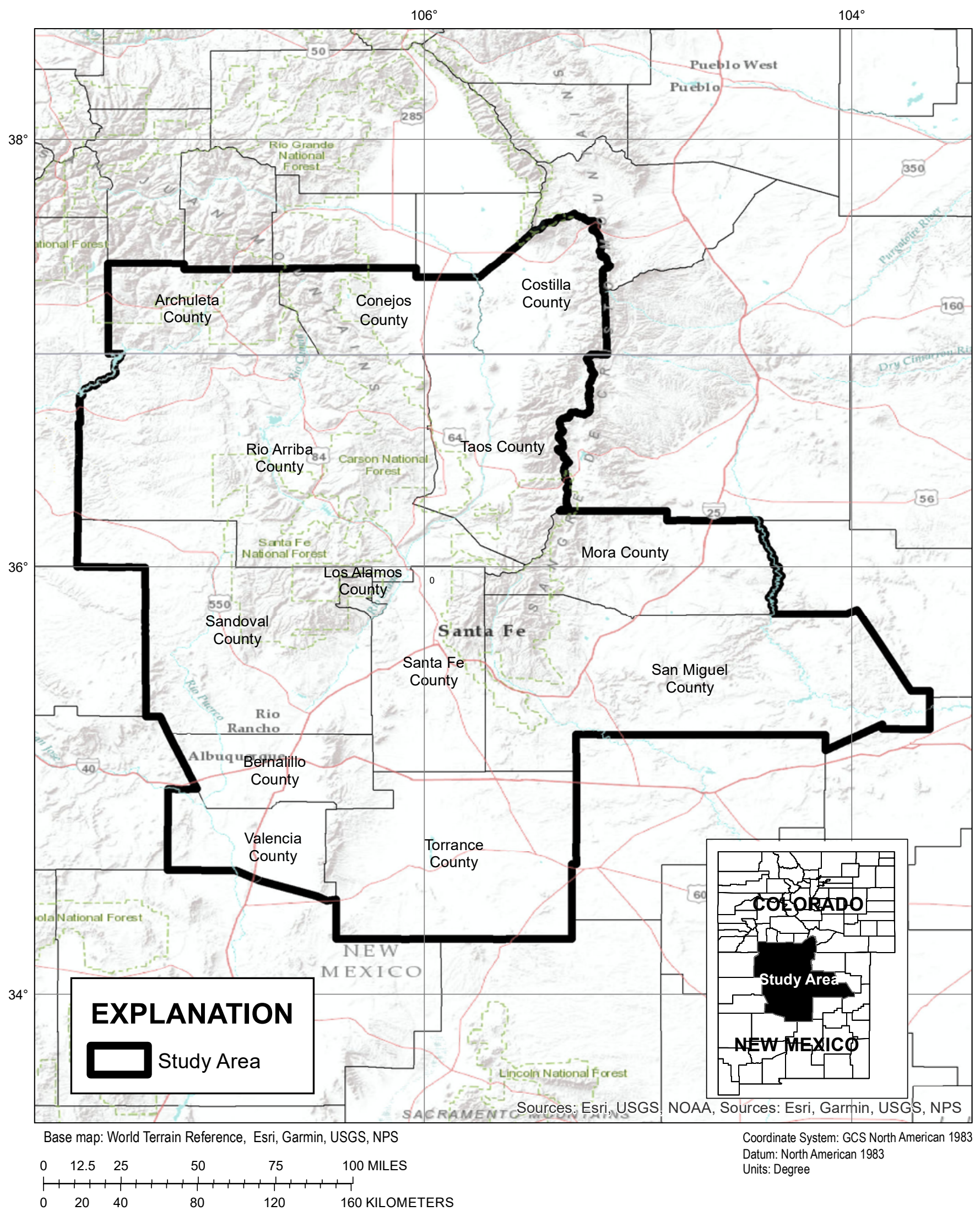

Figure 1. Thirteen-county local economic region included in Rio Grande River Basin wildfire risk reduction and source water protection projects area in northern New Mexico and southern Colorado. Bernalillo, Los Alamos, Mora, Valencia, Rio Arriba, Santa Fe, Sandoval, San Miguel, Taos, and Torrance Counties are in New Mexico, and Archuleta, Conejos, and Costilla Counties are in Colorado. 


\section{Rio Grande Water Fund Project Expenditure Data Collection}

All 2018 expenditure data are were recorded by TNC for the RGWF and were combined into a usable format for economic impact modeling purposes using the USGS restoration cost collection survey (Federal Register [2016], OMB control number 1028-0107). This survey instrument builds off past USGS research collaborations with the NRDA Restoration Program, the BLM, and the USFS (see Cullinane Thomas and others, 2016). In addition to the restoration case studies described in Cullinane Thomas and others (2016), a modified survey has since been used in studies for the National Park Service to estimate the economic impacts of park-specific restoration projects (Cullinane Thomas and others, 2019). The survey instrument asks respondents to classify each restoration action according to the North American Industry Classification System (NAICS) code (https://www.census.gov/eos/ www/naics/), and to provide the total cost of each action, the type of expenditure (in other words, whether it was an in-house, contracted, or materials purchase), and State and County where the hired contractor was located or where the material was purchased.

\section{Economic Regions}

To estimate economic multipliers, the extent of the economic region must first be defined, because economic multipliers reflect the circulation of money within a defined economy. Goods and services purchased from outside of the defined local regional economy are "leaked" from the local economy, and thus do not generate economic activity within the defined region.

This report investigates the economic impacts within the thirteen counties that encompass the RGWF project area boundary. This 13-county local economic region includes ten counties in New Mexico: Bernalillo, Los Alamos, Mora, Valencia, Rio Arriba, Santa Fe, Sandoval, San Miguel, Taos, and Torrance Counties and three Counties in Colorado: Archuleta, Conejos, and Costilla Counties. Since some project expenditures were made outside of the 13-county region, a larger economic region was constructed to encompass the combined Western States regional economy to assess the economic impacts for a broader regional economy beyond the immediate 13-county RGWF project area. This larger region was composed of Arizona, California, Colorado, Idaho, Kansas, Montana, Nebraska, Nevada, New Mexico, North Dakota, Oklahoma, Oregon, South Dakota, Texas, Utah, Washington, and Wyoming.

\section{Data Compilation and Best-Fit Sectors}

All expenditures are grouped by restoration activity according to NAICS codes as reported by TNC, and then bridged to a best-fit IMPLAN sector for impact modeling (table 1). For example, TNC reported geographic information systems (GIS) analysts were hired in support of planning needs, which corresponds to NAICS code 541370 (Geospatial Mapping Services) and is best represented by IMPLAN sector 449 (Architectural, Engineering, and Related Services-Including landscape architecture, building inspections, surveying and mapping, and testing laboratories). Project expenditures are then summed by IMPLAN sector.

Total expenditures made by the RGWF equaled $\$ 855,000$ in 2018 (table 2). Of these expenditures, $\$ 623,000$ (73 percent of total expenditures) were made within the 13-county RGWF project area region (as identified by each awarded contractor's location reported by TNC). "Prescribed burning, tree thinning, and mastication of trees" projects summed by best-fit IMPLAN sector 19 (support activities for agriculture and forestry) had the largest proportion of all expenditures at $\$ 588,000$, among which $\$ 440,000$ (74.9 percent) were spent locally to hire contractors within the 13-county RGWF project area. The remaining $\$ 147,000$ for prescribed burning, tree thinning, and mastication of trees was paid to contractors that reside outside the 13-county RGWF project area and thus are only reflected in the Western States regional model. "Environmental and other technical consulting services and project management," summarized by best-fit IMPLAN sector 455 (environmental and other technical consulting services) had the second largest proportion of all expenditures totaling $\$ 199,000$ in 2018 . Approximately $\$ 116,000$ (58.5 percent) of these expenditures were made locally within the 13-county RGWF project area.

\section{Results}

The economic impacts from RGWF project expenditures are estimated for both the 13-county RGWF project area and the Western States region. Only expenditures made within the defined 13-county RGWF region area ("Local expenditures" column from table 2) are included in the RGWF local region economic impact model. All expenditures ("Total expenditures" column from table 2) are included in the Western States regional economic impact model.

The regional economic impacts from the $\$ 622,950$ spent within the 13 -county local region in the RGWF project area are estimated (table 3). Including direct and secondary effects, these expenditures support an estimated 15 jobs, $\$ 676,000$ in labor income, $\$ 791,000$ in value added, and \$1,120,000 in economic output within the 13-county RGWF project area. 
Table 1. Restoration activity, best-fit IMPLAN sector, and sector description of expenditures made by the Rio Grande Water Fund (RGWF), 2018.

[NAICS, North American Industry Classification System; EA, environmental assessment; GIS, geospatial information systems]

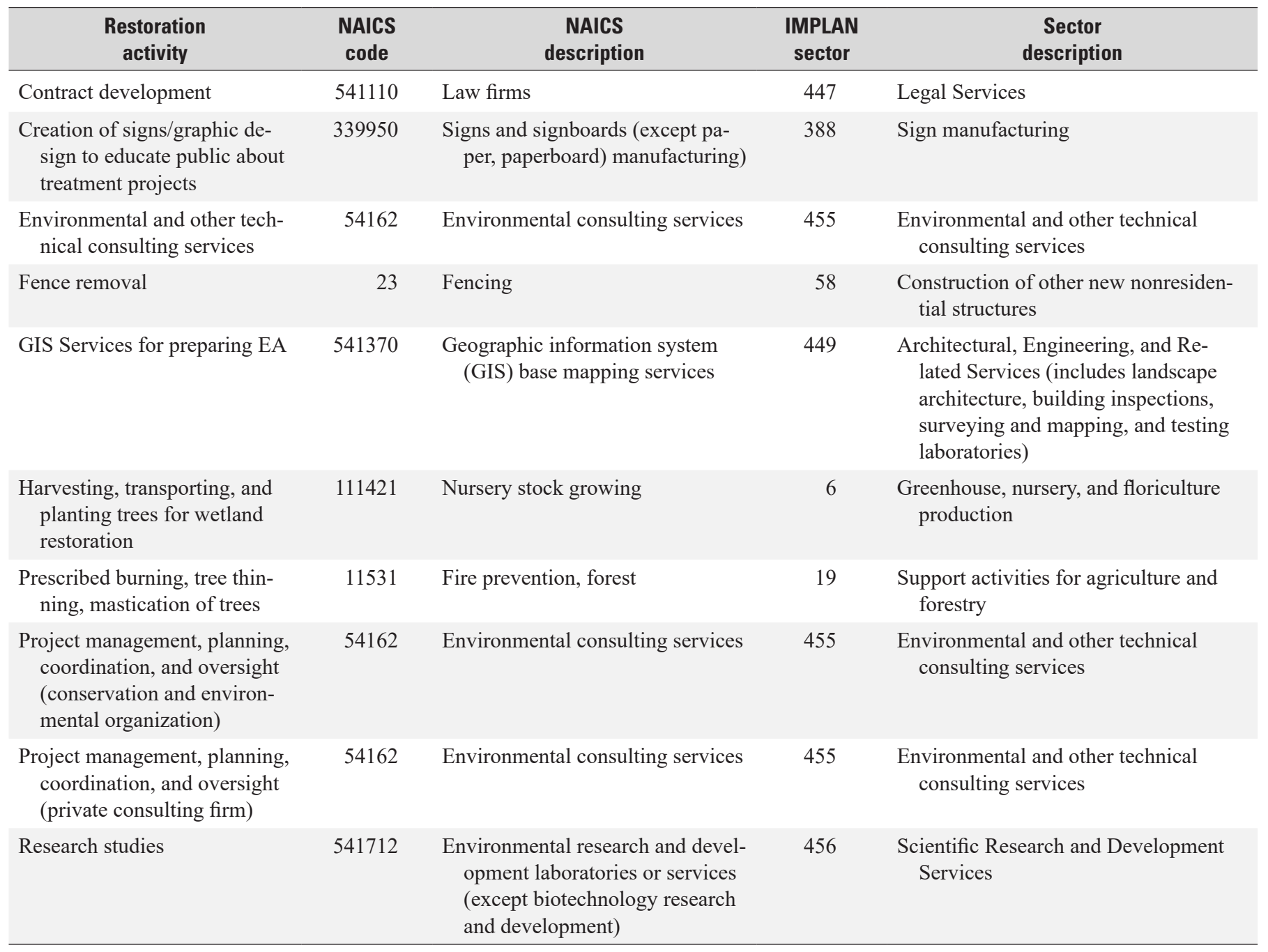

Table 2. Rio Grande Water Fund expenditure categories by IMPLAN sector, total project expenditures in the Western States region, local project expenditures in the 13-county Rio Grande Water Fund project area in northern New Mexico and southern Colorado, 2018, as a result of investments made by the Rio Grande Water Fund (RGWF).

[GIS, geographic information system; EA, environmental assessment]

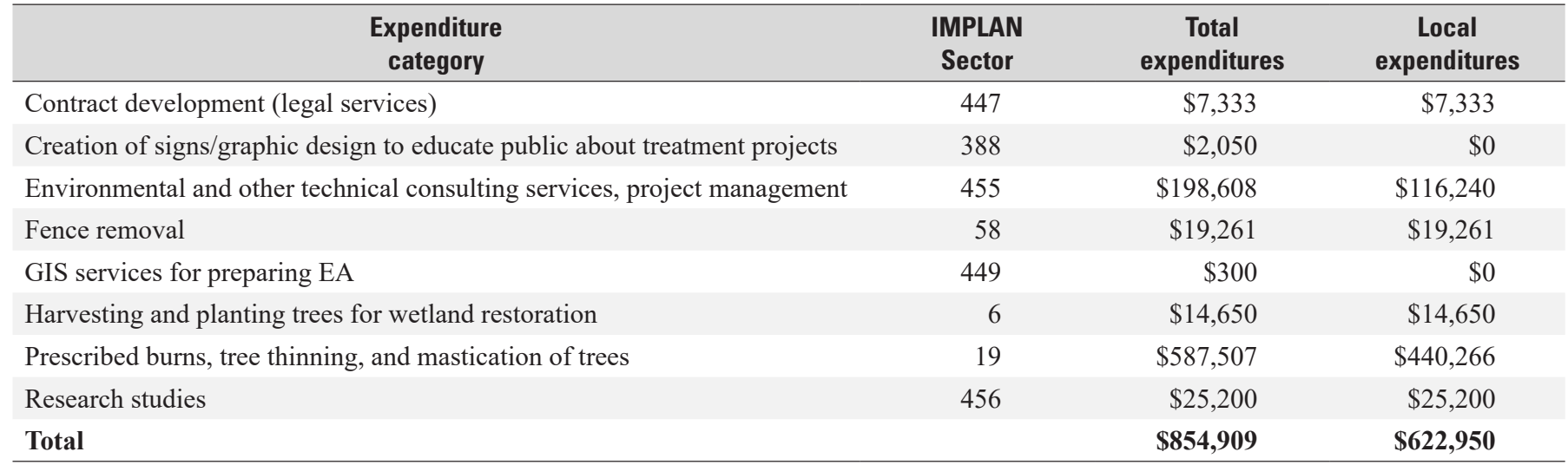


Next, we focused our attention on the regional economic impacts from all project expenditures $(\$ 855,000)$ spent within the broader Western States region (table 4). Including direct and secondary effects, expenditures support an estimated 22 jobs, $\$ 1,089,000$ in labor income, $\$ 1,324,000$ in value added, and $\$ 1,907,000$ in economic output within the Western States region.

Table 3. Economic impacts of project expenditures in 13-county local region of the Rio Grande Water Fund (RGWF) project area, in northern New Mexico and southern Colorado.

\begin{tabular}{lrccr}
\hline \multicolumn{1}{c}{$\begin{array}{c}\text { Impact } \\
\text { Measure }\end{array}$} & Jobs & $\begin{array}{c}\text { Labor } \\
\text { Income }\end{array}$ & $\begin{array}{c}\text { Total Value } \\
\text { Added }\end{array}$ & Output \\
\hline Direct Effect & 11.5 & $\$ 523,084$ & $\$ 509,495$ & $\$ 622,950$ \\
Secondary Effect & 3.8 & $\$ 153,112$ & $\$ 282,060$ & $\$ 497,868$ \\
Total Effect & 15.3 & $\$ 676,197$ & $\$ 791,555$ & $\$ 1,120,818$ \\
\hline
\end{tabular}

Table 4. Economic impacts of project expenditures in the Western States region, beyond the immediate 13-county Rio Grande Water Fund project area in northern New Mexico and southern Colorado. This larger region was composed of Arizona, California, Colorado, Idaho, Kansas, Montana, Nebraska, Nevada, New Mexico, North Dakota, Oklahoma, Oregon, South Dakota, Texas, Utah, Washington, and Wyoming.

\begin{tabular}{lrrrr}
\hline \multicolumn{1}{c}{$\begin{array}{c}\text { Impact } \\
\text { Measure }\end{array}$} & Jobs & $\begin{array}{c}\text { Labor } \\
\text { Income }\end{array}$ & \multicolumn{1}{c}{$\begin{array}{c}\text { Total Value } \\
\text { Added }\end{array}$} & \multicolumn{1}{c}{ Output } \\
\hline Direct Effect & 15.4 & $\$ 735,212$ & $\$ 710,191$ & $\$ 854,909$ \\
Secondary Effect & 6.5 & $\$ 354,149$ & $\$ 614,739$ & $\$ 1,052,455$ \\
Total Effect & 21.9 & $\$ 1,089,361$ & $\$ 1,324,930$ & $\$ 1,907,364$ \\
\hline
\end{tabular}

The economic impacts of restoration can be reported in terms of impacts per million dollars directly spent on restoration, which enables "back-of-the-envelope" comparisons and estimates of the possible impacts of future restoration projects and plans. However, careful attention should be paid when transferring economic impact estimates; specifically, normalized impact estimates should only be used for projects that are composed of a similar set of restoration activities, have a similar landscape scope, and are within the same regional economy. (See Cullinane Thomas and others [2016] for additional guidance and caveats on transferring economic impact estimates). For this analysis, we normalized project expenditures on a per one-million-dollar basis for all expenditures made in the Western States region. Including direct and secondary effects, one million dollars spent on landscape-scale forest restoration treatments supports an estimated 26 jobs, $\$ 1,274,000$ in labor income, $\$ 1,549,000$ in value added, and \$2,231,000 in economic output within the Western States region. These normalized per million-dollar economic impact estimates can only be used to estimate the impacts of other RGWF projects with a similar blend of restoration activities completed by contractors who are located within the defined Western States region (Cullinane Thomas and others, 2016).

\section{Conclusions}

Investments in wildfire risk reduction and source watershed protection projects in northern New Mexico and southern Colorado affected local economic activity. In 2018, the RGWF spent a total of $\$ 855,000$ on contractors located the Western States region. These expenditures supported an estimated 22 jobs, $\$ 1,089,000$ in labor income, $\$ 1,324,000$ in value added, and $\$ 1,907,000$ in economic output in the Western States regional economy. Seventy-three percent (or $\$ 623,000$ ) of total expenditures were made by hiring local businesses operating within the RGWF project area covering a 13-county region in northern New Mexico and southern Colorado. Including direct and secondary effects, local expenditures supported an estimated 15 jobs, $\$ 676,000$ in labor income, $\$ 791,000$ in value added, and $\$ 1,120,000$ in economic output within the 13-county RGWF project area. These results illustrate how investments in wildfire risk reduction and source water protection projects can support jobs and livelihoods within the local economy. 


\section{References Cited}

BenDor, T., Lester, T.W., Livengood, A., Davis, A., and Yonavjak, L., 2015, Estimating the size and impact of the ecological restoration economy: PLoS ONE, v. 10, no. 6, accessed June 14, 2019, at http://dx.doi.org/10.1371/journal.pone.0128339.

Champ, P.A., Boyle, K.J., and Brown, T.C., eds., 2017, Primer on Nonmarket Valuation, (2d ed.): The Netherlands, Springer, $504 \mathrm{p}$.

Cullinane Thomas, C., Huber, C., Skrabis, K., and Sidon, J, 2016, Estimating the economic impacts of ecosystem restorationMethods and case studies: U.S. Geological Survey Open-File Report 2016-1016, 98 p., accessed August 12, 2019, at http://dx.doi.org/10.3133/ofr20161016.

Cullinane Thomas, C., Van Gilder, N., and VanMouwerik, M., 2019, Economic impacts of restoration in National Parks: National Park Service, Natural Resource Report NPS/NRSS/EQD/NRR—2019/1860, accessed August 12, 2019, at https://irma.nps.gov/DataStore/DownloadFile/617996.

Edwards, P.E.T., Sutton-Grier, A.E., and Coyle, G.E., 2013, Investing in nature—Restoring coastal habitat blue infrastructure and green job creation: Marine Policy, v. 38, p. 65-71., accessed Nov. 22, 2019, at https://doi.org/10.1016/j.marpol.2012.05.020.

Federal Register, 2016, Information collection activities-Request for comments: Office of the Federal Register, National Archives and Records Administration, v. 81, issue 127, 81 FR 43224, p. 43224-43225, accessed August 12, 2019, at https://www.govinfo.gov/content/pkg/FR-2016-07-01/html/2016-15657.htm.

Headwaters Economics, 2014, The economic impacts of restoration - Custer and Lemhi Counties, Idaho: Headwaters Economics, 16 p., accessed June 14, 2019, at http://headwaterseconomics.org/wphw/wp-content/uploads/Idaho_Restoration_Report.pdf.

Hjerpe, E.E., and Kim, Y-S., 2008, Economic impacts of southwestern National Forest fuels reductions: Journal of Forestry, v. 106, no. 6, p. 311-316. [Also available at https://academic.oup.com/jof/article/106/6/311/4598837.]

IMPLAN Group LLC, 2018, IMPLAN System (data and software) 2017 national data set: Huntersville, N.C., IMPLAN, accessed June 12, 2019, at https://www.IMPLAN.com.

Industrial Economics, 2012, Economic impacts of ecological restoration in Massachusetts-Summary of report findings: Massachusetts Department of Fish and Game, Division of Ecological Restoration, 30 p., accessed June 14, 2019, at http://www.mass.gov/eea/docs/dfg/der/pdf/economic-impacts-ma-der.pdf.

Johnston, R.J., Besedin E.Y., and Stapler R., 2016, Enhanced geospatial validity for meta-analysis and environmental benefit transfer-An application to water quality improvements: Environmental and Resource Economics, v. 68, issue 2, 41 p. [Also available at https://link.springer.com/article/10.1007/s10640-016-0021-7.]

Kim, Y.-S., 2010, Ecological restoration as economic stimulus-A regional analysis: Flagstaff, Ariz., Northern Arizona University Ecological Restoration Institute, 20 p., accessed June 14, 2019, at http://ibrary.eri.nau.edu/gsdl/collect/erilibra/ index/assoc/HASH01a0/f2bebf05.dir/doc.pdf.

Laughland, D., Phu, L., and Milmoe, J., 2014, Restoration returns-The contribution of Partners for Fish and Wildlife Program and Coastal Program restoration projects to local U.S. economies: U.S. Fish and Wildlife Service, 42 p., accessed June 14, 2019, at http://www.fws.gov/home/pdfs/restoration-returns.pdf.

Loomis, J.B., 2002, Integrated public lands management—Principles and applications to National Forests, Parks, Wildlife Refuges, and BLM lands: Columbia University Press, 544 p. [Also available at https://www.jstor.org/stable/10.7312/loom12444.]

Loomis, J.B., and Walsh, R.G., 1997, Recreation economic decisions; comparing benefits and costs: Andover, Mass., Venture Publishing Inc., $440 \mathrm{p}$.

Nielsen-Pincus, M., and Moseley, C., 2010, Economic and employment impacts of forest and watershed restoration in Oregon: Eugene, Oreg., University of Oregon, Institute for a Sustainable Environment, Ecosystem Workforce Program, Working Paper Number 24, 28 p., accessed June 10, 2019, at http://www.oregoncoastalliance.org/documents_13/Restoration_Economy_ Study_2010.pdf. 
Richardson, L., and Loomis, J., 2009, The total economic value of threatened, endangered and rare species — An updated metaanalysis: Ecological Economics v. 68, issue 5, p. 1535-1548. [Also available at https://doi.org/10.1016/j.ecolecon.2008.10.016.]

Southwick Associates and Responsive Management, 2013, Economic impact analysis of the collaborative forest landscape restoration program: Responsive Management, 20 p., accessed June 14, 2019, at http:/www.fs.fed.us/restoration/documents/cflrp/ results/AcceleratingLongleaf/EconomicAnalysisCFLRPreport.pdf.

The Nature Conservancy (TNC), 2014, Rio Grande Water Fund-Comprehensive plan for wildlife and water source protection, July 2014: The Nature Conservancy, accessed August 12, 2019, at http://riograndewaterfund.org/wp-content/uploads/2017/01/ rgwf_compplan.pdf.

U.S. Department of Agriculture, 2015, Collaborative forest landscape restoration program-5-year report, FY 2010-2014: U.S. Forest Service FS-1047, 16 p., accessed August 12, 2019, at https://www.fs.fed.us/restoration/documents/cflrp/CFLRP 5YearReport.pdf.

Wagner, B., and Shropshire, R., 2009, An estimation of Montana's restoration economy: Montana Department of Labor and Industry, Research and Analysis Bureau, 28 p., accessed August 25, 2015, at https://mi.mt.gov/Portals/193/Publications/LMIPubs/Special\%20Reports\%20and\%20Studies/RestorationStudy2009.pdf. 

